\title{
Rethinking the Use of “Should” in Translation Criticism
}

\author{
YANG Zhuo \\ East China University of Political Science and Law, Shanghai, China
}

\begin{abstract}
The use of "should" in the applied translation studies such as translators training, translation aids and translation criticism has proved to be one of the most important tools for progress in the discipline since Holme put forward the basic map of Translation Studies. In this paper, the author discusses mainly the use of "should" in translation criticism, arguing that, the many advantages to be had by this method notwithstanding, there are problems. For example, it is not always fair to judge one translator's work too soon and too sure; and offering overwhelming advice induces disrespect to the translator. For these reasons, the author argues, it is worth exploring ways of translation criticism beyond traditional mode of "should" which may seem subversive of standard uses, either alone or in conjunction with Descriptive Translation Studies (DTS).
\end{abstract}

Keywords: Descriptive Translation Studies, translation criticism, translation ethics

\section{Introduction}

The use of "should" in the applied translation studies such as translators training, translation aids and translation criticism has proved to be one of the most important tools for progress in the discipline since Holme put forward the basic map of Translation Studies in the Third International Congress of Applied Linguistics held in Copenhagen, 1972. Advances made through their use in applied area of translation are well known and well documented (Christ, 1982; Brown, 1994; Venuti, 1998).

In this paper, the author shall be mainly concerned with the use of "should" in translation criticism, and the author shall argue that, even though it is the standard and also valuable way of using prescriptive words in translation training, translation aids and translation criticism, it is worth exploring ways of translation criticism beyond traditional mode of "should" which may seem subversive of standard uses, either alone or in conjunction with Descriptive Translation Studies (DTS). There are two reasons. One is that real-life situations apply different standards of evaluation to the translated text. It is not fair to judge one translator's work too soon and too sure. The other is that once the work of criticism gets published, the translator and the critic are positioned in an unfair power relation in which the latter has the upper hand over the former, and offering overwhelming advice on the side of the critic induces disrespect to the translator. Yet we nevertheless ignore this unfairness and condone such criticism.

\section{The Role of Criticism in Translation Studies}

In James S. Holmes’s “The Name and Nature of translation studies” (Holmes, 1988/2000), he put forward

YANG Zhuo, Ph.D., Lecturer, East China University of Political Science and Law. 
an overall framework, describing what translation studies covers. According to him, translation studies can be divided into "pure” and "applied”. The "applied” branch of Holmes’s framework concerns: translator training, translation aids and translation criticism. As for translation criticism, it concludes the evaluation of translations, including the marking of student translations and the reviews of published translations.

Hence comes the use of "should" in such a category. As Toury has summarized, "the applied extensions cannot be anything but prescriptive" and "they are...to set norms in a more or less conscious way. In brief, to tell others what they should have done and/or should be doing, if they accept these norms (or, very often, the authority of their opponents) and submit to them” (Toury, 1995/2001, p. 19). Toury even points out that the differences between DTS and applied extensions of Translation Studies are "manifested most univocally in the use of verbs". According to him, "verbs of different categories are typical of each branch, and their actual use in a discourse about translation may therefore serve as a marker of its respective place in the discipline" (Toury, 1995/2001, p. 19). In Toury’s opinion, the typical verb for applied extensions of Translation Studies is "should be”.

Indeed, using "should” for pedagogical purpose is understandable, considering in most situations the trainee pays the trainer to get himself corrected. In translation science area, to criticize properly is also indispensable to the course of development. By learning from mistakes, researchers clarify mist and identify better ideas. And such efforts are accumulated into building up a tower of knowledge.

However, it's hard to imagine a translator voluntarily invites someone to criticize his own piece of translating work. Besides, the critic does not necessarily translate better than the translator himself. Ronald Christ even found out that many reviewers were not able to compare ST with TT and restricted themselves to often critical comments on individual words (Christ, 1982, p. 21) and Maier noted that translation reviewing was "largely underdeveloped" and one of the suggestions she made is the need "to corporate the contributions of translation theory and translation criticism into the practice of reviewing” (1990, p. 20).

To see the conflicts the normative studies of translation (using "should") may cause, two cases will be presented and analyzed in the following section.

\section{Case Study}

In the early 20th century of China, when translating a children’s novel, Zhao Jingshen (赵景深) conversed the English term “Milk Way” literally into “Milk Road (牛奶路)” instead of a better-accepted version: “Galaxy (银河)”. His translation was new to Chinese at that time and inflicted public humiliation from a renowned writer, Lu Xun (鲁迅). Being mocked with his ignorance in a ragged verse by Lu (1973), Zhao turned out to be one of the biggest laughing stocks ever in translation history. However, decades later, as China adopts an open-up policy and researchers get to know more about domestication and foreignization approaches, people recalled the story and started writing in the translator's defense (LENG, 1995; ZHANG, 1996; FANG \& ZHANG, 2010). Yet a price has been paid by the avant-garde translator: this scandal cast a shadow on his career all along.

Getting works published brings risks of open criticism. When it comes to translation work, things become harder. In another instance, Prof. Chen Zhongchen (陈忠诚) is our research subject. He is famous for rich knowledge in legal English and little tolerance for any "mistakes" occurred in this area. With a diploma of law from an elite law school before the founding of People's Republic of China, most of his publications are about 
picking flaws in other's work. However, while criticizing, as a bilingual law expert, he's prone to use strong expressions of prescription and he's good at reinforcing his stand with a mocking tone such as "it's hard to believe that ...", "can I beg your attention to this stupid mistake”, or "can I have the opportunity to learn this stuff from you" in an ironic tone. While pointing out "improper" translated terms, he even uses the word "ignoramus" to address other translation professionals (CHEN, 2004).

The two stories are like the two sides of a coin. They reveal that on one hand, criticism may pose pressure on a translator, fair or unfairly, to the extent of ruining his career. On the other hand, a critic tends to play an aggressive role when judging other's translation work, leaving limited space for defense or explanation, resulting in the pressure on the translator.

Behind the two cases are the commonly held assumptions underlying translation evaluation and the use of "should" in translation criticism:

- that a translation work "should" be "correct";

- that the critics have the certain right to criticize the translator;

- that the translator, once found made a "mistake", tends to lose his credibility as a capable professional personnel ever since;

- that translation criticism gets more publicity than the translator's self-defense.

The first assumption is especially implicit in many suggestions for application of criticism either in teaching or in publication. It implies a commonly accepted view on text relations between Source Text (ST) and Target Text (TT), and between the TT and someone's ideal version of the TT.

The rest assumptions, however, can be traced back to the unbalanced power relation between the critic and the translator, a form of manipulation in the name of "should".

The following sections will discuss the text relation and power relation related to the use of "should" respectively.

\section{Use of "Should" in Text Relation}

As mentioned earlier, translation studies can be categorized into two schools: pure or theoretical translation studies and applied translation studies. Accordingly, there exists two schools of translation studies: normative versus descriptive. In normative translation studies, translators are encouraged to adopt certain methods to achieve "equivalence" (Nida, 1964). Translation that is not "equivalent” is considered unsuccessful and needs to be avoided. And that's the motive behind use of "should" by the critic, who holds the assumption that everything "should" be "correct".

However, it's impossible to define what's "correct”. As Pym (1998) and many others have argued, equivalence may be understood as a belief structure, the creation of a pragmatically necessary illusion. Actually translation itself is “bound up with value” (Hermans, 2004, p. 95). “T(t)he correct translation”, according to Theo Hermans, "is a translation which accords with expectations about what a good translation should be" (Hermans, 2004, p. 95) and "correctness" itself is a subjective term of evaluation instead of objective. In reality, in order to achieve the so-called "correctness", the use of "should" is transferred into guidelines and directions. Yet the criteria for "correct" are diversified and subject to context, which means that the use of "should" does not hold much ground as it intends to be. 
A translation work has life. Text relations change. The "correctness" varies. The interpretation of a translation work depends on the readers from different context, and the meaning of it changes along with time and space. From this point of view, instead of regulating a translator with "should", an ethically qualified researcher/critic would refrain from making conclusions too soon and too rigidly.

In this sense, something can be learned from the DTS. Though the descriptivists are unwilling to work toward explicit value judgements regarding translation quality or formulate criteria for accuracy in translation (Newmark, 1991, p. 54), they leave space for exploring new ways of criticizing. As Holmes pointed out years before, theoretical, descriptive and applied areas do influence one another (Holmes, 1988/2000, p. 78) and Peter Newmark also made it clear that "Translation theory's main concern is to determine appropriate translation methods...Further, it provides a framework of principles, restricted rules and hints for translating texts and criticizing translations, a background for problem solving” (Newmark, 1980, pp. 1-2). For DTS, “describing, explaining and predicting phenomena pertaining to its object level”(Toury, 1995/2001, p. 1) is the main goal of such a discipline and the significance of DTS lies "in the possibility of supplying exhaustive descriptions and explanations of actual behaviour” (Toury, 1995/2001, p. 16). By analyzing and comparing source text and target text, language phenomena are described and norms are extracted from the description. Such a study promotes our understanding of "what is translation" generally and thus contributes to our knowledge of philosophy.

The author suggests that, to a critic with descriptive awareness, a translation work that is beyond common acceptation, like "Milk Road", which would have been labelled as something "shouldn't" happen, may be explained as the one that has taken an approach of foreignization, and has introduced new elements into target culture, meanwhile it draws the reader closer to the source culture. By taking such a move, firstly, the critic drops the old-fashioned way of criticizing with "should" or "shouldn't". Instead, he describes text relations between ST and TT without overdosed value judgment. Secondly, by summarizing and explaining text relations, the criticism is successfully realized "to its object level". Thirdly, as the critic discloses the rules of translation using the verb "is", readers are left with space to ponder over and draw conclusions themselves.

In a word, while the use of "should" dictates fixed text relations between ST and TT, criticism adopting the approach of DTS may win its readers with facts instead of opinions. And it relieves the readers from the burden of accepting the critic's ideal version of the TT unconditionally.

\section{Use of "Should" in Power Relation}

Translation texts do not come from nowhere. As translation researchers mostly deal with theories and texts, translation criticism involves people. When the critic points his finger at a text, a paper or some research data, there are people who translate, write or collect them. Behind the critic, there exists a powerful network of the publishing industry. That explains why Toury addressed the branch of "translation criticism" as "an extension 'into the world' of the discipline, but not of it alone” (Toury, 1995/2001, p. 18).

In this publishing industry, the translator plays a weak role, as Fawcett (1995, p. 189) described the complex network as amounting to a "power play", with the final product considerably shaped by editors and copy-editors. In this power play, by stating what "should" have been done by the translator, a critic is entitled to judgement and he decides which version of translation is "corrector" than the other. In the above mentioned two cases, considering Lu Xun and Chen's superior social positions to the translators, people tend to agree with them not 
because of the "correctness" but because of their previously-gained social credibility. Similarly, a critic can always avail himself of such convenience to have the crowd to choose between him, an established icon, and a novice translator in the translation circle. Face with such a challenge, a translator failing to defend for himself publicly may have his academic career sabotaged, if not totally ruined. This is how the criticism in the name of "should" induces power imbalance.

Take the case of Prof. Chen, again, for an example. On one hand, he is obsessed with minor errors such as the typos (which of course deserves pungent scolding, yet shouldn't be elaborated too much on) which dilutes the significance of the whole research. On the other hand, instead of focusing on the facts, his criticism was directed at people, causing irrevocable harm to someone's fame, and such a move even constituted personal attacks. These problems are the representation of power imbalance.

To tackle such problems, the author promotes one principle of ethics: non-maleficence, which means "do no harm". Of course the use of "should" itself does not violate such principle of ethics. It elicits harm both on individual and business level only if: the person being pointing fingers at is muted, having no chance to defend for himself; the critic's academic status is overwhelmingly higher than his counterpart; the argument is over trivial issues, which barely match the contribution someone has made in the area of study; while judging other's work, comments and suggestions are absolute and final, allowing no space for alternation or improvement later on; the point of view is strong and even biased, showing lack of objectivity. In a word, so long as the critic has status advantages over the translator and judges the latter's work overwhelmingly with the use of "should", the power relation is unbalanced and unfairness arises.

\section{Conclusion and Suggestion}

What we have discussed is problems of normative translation criticism with the marker of "should". Despite an commonly accepted idea that the application of translation studies may involve a set of "bridging rules" (Toury, 1995/2001, p. 18), the use of "should" postulates fixed text relations between ST and TT and reinforces the unequal power relation between the critic and the translator. Critic may have hidden ideology behind his criticism, yet the criticism should go beyond identification of errors. To quote Hermans: "the study and the theory of translation has its rationale in the benefit that can accrue from it for the practice of translating and of translator training” (Herman, 2004, p. 151). Considering the deleterious impact of criticizing unethically both on the individual and on the the discipline, the DTS approach offers, at least partly, solution to the problems and may shed light on the discipline's future progress.

The following principles are recommended to avoid pitfalls of highly intuitive or subjective criticism:

- The criticism is openly published and welcomes any counter opinions;

- Base the criticism on facts instead of regulations;

- Apologize first if the criticism might cause emotional disturbance on the translator; use neutral expressions;

- Focus on the significant part of the work; ensure that the argument is constructive to both parties involved and to the subject of science;

- Knowing it's risky to jump at an absolute conclusion without flexibility in arts of science unless you are $100 \%$ sure about this point of view;

- Use impersonal language; respect people who are under criticism; no personal or biased judgment against others. 
The most of we can hope for is for the critics to reconsider their use of "should" and to reflect the impact of their overwhelmed advice on text and power relations. Above all, criticizing convincingly is realized through criticizing ethically.

\section{References}

Brown, M. H. (1994). The reception of Spanish American fiction in West Germany 1981-91. Tubingen: Niemeyer.

CHEN, Z. C. (2004). 向翻译译审者请教 (A discussion with the translation reviewers). Retrieved from http://www.chinalaw.gov.cn/article/jggz/ysyd/llyj/200412/20041200035916.shtml

Christ, R. (1982). On not reviewing translations: A critical exchange. Translation Review, 9,16-23.

FANG, X. Y., \& ZHANG, H. M. (2010). 从“牛奶路公案”浅析鲁迅的翻译观 (A tentative discussion of Lu Xun’s idea of translation: A case study of the “Milk Road”). 文艺生活·文艺理论 (Literature Life), (8).

Fawcett, P. (1995). Translation and power play. The Translator, 1(2), 177-92.

Hermans, T. (2004). Translation in systems: Descriptive and system-oriented approaches explained. Shanghai: Shanghai Foreign Language Education Press.

Holmes, J. S. (1988/2000). The name and nature of translation studies. In L. Venuti (Ed.), The translation studies reader (pp. 172-85). London and New York: Routledge.

LENG, Z. X. (1995). 无可厚非的“牛奶路” (The unblamable “Milk Road”). 鲁迅研究月刊 (Luxun Research Monthly), (3).

LU, X. (1973). 风马牛(Feng Ma Niu). In 鲁迅全集 (Lu Xun’s Collections) (p. 338). Beijing: People’s Literature Press.

Maier, C. (1990). Reviewing Latin American literature. Translation Review, 34(5),18-24.

Newmark, P. (1991) About translation. Clevedon: Multilingual Matters.

Newmark, P. (1980). What translation theory is about. Quinquereme, 3(1), 1-21.

Nida, E. A. (1964). Toward a science of translating. Leiden: E. J. Brill.

Pym. A. (1998). Method in translation history. Manchester: St. Jerome.

Toury, G. (1995/2001). Descriptive translation studies and beyond. Amsterdam/Philadelphia: John Benjamins/Shanghai: Shanghai Foreign Language Education Press.

Venuti, L. (1998). The scandals of translation: Towards an ethics of difference. London and New York: Routledge.

ZHANG, Z. Y.(1996). 鲁迅的“硬译”与赵景深的“牛奶路” (The “Hard Translation” of Lu Xun and Zhao Jingshen’s “Milk Road”). 鲁迅研究月刊 (Luxun Research Monthly), (7).

ZHAO, J. S. (1922). 㚞凯 (Vanka). In 悒郁 (The sadness). Beijing: Kaiming Press. 